\title{
Poznámky na okraj výsledků výzkumu k vnitrostátnímu soudcovskému zacházení s judikaturou Evropského soudu pro lidská práva
}

\author{
Sidelight on the Results of Research into National Judicial \\ Treatment of the European Court of Human Rights' Case Law
}

\author{
Vít Alexander Schorm*
}

\begin{abstract}
Abstrakt
Na okraj kniby Domestic Judicial Treatment of European Court of Human Rights Case Law: Beyond Compliance, ježje zpprávou o tom, jak naše vrcholné soudy naplinuji Evropskou úmluvu o lidských právech, autor ve svých poznámkách konstatuje, ̌̌e nenaplnováni Úmluvy je protisystémové jednáni a vnitrostátní soudy by v pochybnostech či prì nesoublasu mèly s Evropským soudem pro lidskáa práva zásadnè vést dialog. To, že výzkum neodhalil žádné qávažné nedostatky, zapadá do př̌nivébo kontextu České republiky a aktivit souvisejicich s výkonem rozsudku Soudu. Odpovédi věech trü vrcholných soudu na právni problémy analyzované na mikeroúrovni nemusi být z. blediska judikatury Soudu vždy uspokojivé (zásada ne bis idem nebo úredni zmèna pohlaví). Nèkedy museji soudy reagovat na obavy zákonodárce z otevréní právní úpravy (restituce majetku nebo regulace nájemnébo). V oblasti vadèláváni romských dèti se soudy prakticky neangažovaly, a to pro nedostatek vhodných návrbi na zabájeni ř́zeni. Kniba je podle autora clánku kaminkem v dosud nedokončené mozaice ₹koumáníproblematiky dodržování lidskoprávních závazkù státy.
\end{abstract}

Klíčová slova

Evropský soud pro lidská práva; výkon rozsudku Evropskébo soudu pro lidská práva; Ústavní soud; Nejvy šsi soud; Nejvyšš správni soud; respektováni judikatury Evropskébo soudu pro lidská práva;

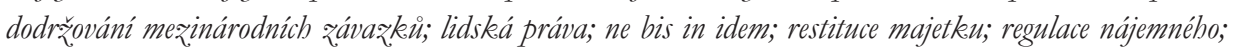
úredni zmèna poblavi; vadèláváni romských dètí.

\section{Abstract}

The book Domestic Judicial Treatment of the European Court of Human Rights Case Law: Beyond Compliance analyses how our Czech apex courts comply with the European Convention on Human Rights. This article posits that non-compliance with the Convention is anti-systemic conduct and national courts should lead dialogue with the European Court of Human Rights in case of doubt or disagreement with its case law. The fact that the book did not reveal any serious shortcomings fits into the favourable context of the Crech Republic and the activities related to the enforcement of Court judgments. The answers of all

JUDr. Vít Alexander Schorm, vládní zmocněnec pro zastupování před Evropským soudem pro lidská práva / Government Agent before the European Court of Human Rights, Czech Ministry of Justice, Czech Republic / E-mail: vschorm@msp.justice.cz

Názory autora vyjádřené $\mathrm{v}$ této stati, třebaže se opírají o poznatky z dlouhodobého působení na této pozici, nejsou přičitatelné České republice. 
three apex courts to legal problems analysed at the micro-level may not always be satisfactory from the point of view of the case law of the European Court (ne bis idem principle or official gender reassignment). Sometimes, domestic courts have to respond to the legislator's concerns about amending legislation (restitution of property or rent control). In the issue of education of Roma children, the courts were not much involved, due to the lack of suitable proposals to initiate proceedings. This article concludes that the book is a stone in the bitherto unfinished mosaic of research into the issue of state compliance with buman rights obligations.

\section{Keywords}

The European Court for Human Rights; Enforcement of Judgments of the European Court of Human Rights; the Czech Constitutional Court; the Czech Supreme Court; the Czech Supreme Administrative Court; Following the Case Law of the European Court of Human Rights; Compliance with International Obligations; Human Rights; ne bis in idem; Property Restitution; Rent Regulation; Official Gender Reassignment; Education of Roma Children.

\section{Úvod}

Dostává se mi do rukou kniha Domestic Judicial Treatment of European Court of Human Rights Case Law: Beyond Compliance, jež je zprávou o tom, jak naše vrcholné soudy naplňují Evropskou úmluvu o lidských právech, závaznou pro Českou republiku od roku 1992. Nespíš bych na prvním místě zdůraznil, že výzkum na pozadí této knihy považuji za poctivý. Na zkoumanou materii zvolili výzkumníci tři různé perspektivy, které v knize popisují - makro-, mezo- a mikroúroveň - a které jdou od hrubých počtů přes roli sehrávanou judikaturou Evropského soudu pro lidská práva ve vnitrostátním rozhodnutí až po konkrétní ilustrace př́stupů jednotlivých vrcholných soudů k práci s Úmluvou a navazující judikaturou Soudu.

Je pravda, že autoři zvolili jako př́klad Českou republiku s jejími specifickými charakteristikami země střední a východní Evropy, která se vymanila ze systému, jenž nedbal lidských práv a svobod, v roce 1989 a která bez velkých potíží převzala právo Úmluvy a začlenila ho do svého právního řádu. Zvolené postupy však lze použít i v jiných státech, které by se mohly stát předmětem zkoumání s cílem srovnat zjištěné výsledky.

Navíc se tento výzkum zařadil mezi další počiny podobného druhu v oblasti zjišt'ování, do jaké míry státy dodržují své mezinárodní lidskoprávní závazky, jaké jsou předpoklady toho, že státy své závazky dodrží, či jaké jsou naopak protichůdné faktory, a to nejenom tam, kde působí soudní moc coby konečná strážkyně základních práv a svobod jednotlivců v systému právního státu, ale celkově. Soudní moc totiž nemůže být v této oblasti ponechána jako pomyslný ,kưl v plotě‘, pilír, na jehož bedrech by spočívala tíha veškeré odpovědnosti za dodržení závazků.

Považuji tudíž za skvělé, že takový příspěvek ke zkoumání za Českou republiku máme. Chtěl bych kolektivu výzkumníků poblahoprrát $\mathrm{k}$ dosaženému výsledku. Přesto bych na úvod, abych se jimi dále nemusel zabývat, zmínil několik málo dílem kritických postřehů, které jsem si při čtení knihy uvědomil. 
Třebaže je jak výzkum, tak samotný výstup z něho v podobě publikace kolektivním dílem a na knize se podílelo celkem šest autorů, jednotlivé kapitoly si zachovávají vcelku jednotné pojetí - to je nesporně pozitivní. Kniha je sepsána v angličtině, což umožňuje ji zařadit do mezinárodní vědecké diskuse o problematice dodržování lidskoprávních závazků. Současně to brání jejímu bezprostřednímu rozšíření mezi české čtenáře. Překážka to není úplně zásadní, byt' by bylo - jak se ř́ká - fajn, kdyby se tato angličtina úzkostlivě držela o něco jednodušší slovní zásoby a neobsahovala obraty, které bych zařadil spíše do žargonu než do mluvy srozumitelné těm, kdo nikdy nestudovali na britských či amerických univerzitách.

A jako příslušník určité skupiny uživatelů, kteří potřebují rychle pochytit hlavní myšlenky a seznámit se s výsledky, mám navíc trochu potíž s tím, že mi chybí manažerské shrnutí a podobně jako v jiných vědeckých publikacích postrádám i tady zvýrazněné části textu, které by poutaly pozornost ke klíčovým postřehům. A tak, alespoň z mého subjektivního hlediska, není divu, že jsem nutnost pročíst třísetstránkovou publikaci považoval za jistou výzvu.

Líbilo by se mi konečně, kdyby se autoři nedrželi jen svých konstatování zjištěných výzkumem, ale poskytovali také určitý návod na to, jak věci dělat lépe. Zde však patrně narážíme na meze toho, co je primárním vědeckým výzkumem, na rozdíl od výzkumu aplikovaného, který takové rady pro praxi dává. Lze jistě argumentovat tím, že praktikům takový výzkum dovoluje lépe pochopit zkoumané dění, což jim dále umožňuje přijít s nápady, jak toto dění žádoucím způsobem ovlivnit, a že koneckonců vědcům ani nepř́isluší definovat, co je žádoucí, a co již nikoli.

Své poznámky na okraj knihy bych rozdělil mezi obecné a specifické, nebot' je zaměřím na zkoumanou mikroúroveň.

\section{Obecné úvahy}

V tomto rámci bych krátce vysvětlil, proč považuji dodržování Úmluvy za pozitivní jev, okomentoval zjištění výzkumu ohledně situace v České republice a uvedl pár poznámek $\mathrm{k}$ roli vládního zmocněnce ve vztahu k soudům.

\subsection{Význam dodržování či naplňování Úmluvy (compliance)}

Tuto otázku pojímám v tomto svém krátkém pojednání mnohem méně dalekosáhlým způsobem, než k jakému by mohla svádět. Ostatně výzkum samotný se jí také zabýval jen v tom rozsahu, v němž naše vrcholné soudy respektují judikaturu Soudu. Výklad, který Soud ve svých rozsudcích a rozhodnutích podal, může př́ipadně narážet na odpor, který se projeví někde na škále mezi krajními body ,skrytý‘ a ,otevřený‘. Soudy, na rozdíl od orgánů politické moci, mají spíše sklon svůj odpor skrývat. Koneckonců, i vnitrostátní soudní systém stojí na myšlence jednoty, kterou po výkladové stránce zajišt’ují 
právě vrcholné soudy; ty také nejspíše podobným prismatem vnímají svůj vztah k mezinárodním soudům, pokud nežijí v představě vlastní suverenity a neomylnosti.

Úmluva je kodexem našich liberálních závazků, na nichž stojí také demokracie a právní stát. Vytváří svým kontrolním mechanismem určitý systém naplňování či prosazování, třebaže nezachází tak daleko jako Evropská unie, jež považuje každý vnitrostátní soud současně za soud unijní. Skrze mechanismus předběžné otázky totiž existuje př́imá provázanost mezi všemi vnitrostátními soudy a Soudním dvorem Evropské unie, která chybí u práva Úmluvy - zatím ani Česká republika neratifikovala Protokol č. 16 k Úmluvě, ani Evropská unie nepřistoupila k Úmluvě, což jsou svou povahou navíc poměrně slabé nástroje pro zajištění této provázanosti.

Na každý pád však nenaplňování Úmluvy představuje protisystémové jednání, nerespektování existující hierarchie mezi vnitrostátními soudy a Soudem z hlediska tvorby právního názoru (výkladu Úmluvy). V prrípadě nesouhlasu s právním názorem Soudu by vnitrostátní soudy měly respektovat existenci systému práva Úmluvy včetně jeho kontrolního mechanismu a vést dialog. Ten v prvé řadě předpokládá, že vnitrostátní soud zná právo Úmluvy, jak ji vykládá Soud, argumentačně se s tímto výkladem vypořádá a pak vyčká odpovědi, která se dostaví - bohužel nezřídka po dlouhé době - za předpokladu, že je podána stížnost, která projde sítem přijatelnosti. Protokol č. 16 může tento sled událostí obejít a skrze vyžádání posudku vyjasnit právní výklad mnohem dřive, a to i se zřetelem k pochybnostem, které předchozí judikatura Soudu podle mínění vrcholného vnitrostátního soudu vyvolává.

Ve shrnutí je tedy Úmluva souborem závazků všech českých státních orgánů. Nekvalifikované nerespektování výkladu, který Soud podal, znamená rozvratné jednání, na které bych měl rozhodně sklon nahlížet kriticky jako na negativní fenomén.

\subsection{Obrázek České republiky}

Stručně řečeno, výzkum zjistil, že tento obrázek je celkově dobrý. Všechny tři vrcholné soudy berou judikaturu Soudu v potaz, i kdyby tomu tak bylo pouze v rovině argumentačního doplnění. Třebaže mohou rozhodnutí našich soudů ve skutečnosti umně skrývat odpor (jak do jisté míry ukazuje uskutečněné zkoumání na mikroúrovni), není to vyjádřením odporu proti systému Úmluvy jako takovému.

Existují mechanismy, jimiž se na jednotlivých vrcholných soudech průběžně i ad hoc šíŕí informace o judikatuře Soudu z vnitřních i vnějších zdrojů (interní souhrny či bulletiny vydávané samotnými soudy; externí časopisy či rovněž bulletiny). Soudci mají možnost si vyžádat analýzu sporných otázek od specialistů v analytických útvarech. Rovněž přezkoumatelnost rozhodnutí nejvyšších soudů ze strany Ústavního soudu přispívá k tomu, že se lidskoprávní pohled prosazuje či alespoň dostává větší šanci na prosazení, nebot' se v ústavních stížnostech lze Úmluvy a judikatury Soudu dovolávat a také se to často 
děje. $K$ témuž cíli směřuje i institut obnovy řízení o původně podané ústavní stížnosti v př́padech, kdy se - lidově řečeno - něco nepovedlo a Štrasburk to zkritizoval.

Určité omezení širší platnosti výzkumu spočívá v tom, že v České republice přetrvává př́znivý kontext. Na straně jedné jsme postkomunistická země, na straně druhé tu však panuje značná nezávislost soudců všech úrovní, která notně přispívá k jejich odolnosti vưči politickým tlakům. Soud ve Štrasburku také proti České republice nerozhodoval mnoho politicky nebo celospolečensky citlivých př́padů a v poslední době - po roce 2012 - vydal vůbec poměrně málo rozsudků, což není dáno jen tím, že by nebylo o čem rozhodovat; naopak, řada českých stížností na Soudě roky utěšeně leži. ${ }^{1}$ Můžeme mít pocit, že všechno $\mathrm{v}$ podstatě uspokojivě funguje, závazky se naplňují, opatření k nápravě po odsuzujících rozsudcích Soudu se přijímají, přičemž jedinou skvrnu na pověsti představuje výkon rozsudku D. H. a ostatní o vyčleňování romských dětí mimo hlavní vzdělávací proud. ${ }^{2}$

Už z této rychlé charakteristiky vyplývá, že se př́iznivý kontext může snadno změnit.

$\mathrm{K}$ tomu prristupuje i fenomén banalizace lidských práv, která už nejsou vnímána jen jako jednoznačné dobro. Ačkoli je určitě v pořádku, pokud mechanismy k jejich prosazování skrze soudy v zásadě fungují, a tak mnohdy ani nevzniká potřeba politického zásahu k jejich prosazení - lidská práva jsou přece v prvé řadě právy, nikoli politickými požadavky -, jisté znepokojení nutně musí vyvolávat vymizení tohoto tématu z politického diskursu (proč je tomu v jiných zemích na západ od České republiky jinak?), př́ípadně překrucování smyslu a účelu lidských práv v tomto diskursu. Zmínka o svobodě projevu, která by měla pokrývat také šíření fake news, nebo o rozporu mezi právy menšin či jinak znevýhodněných skupin (Romové, migranti) v protikladu k právům většiny anebo o potlačování právního rozměru určitých otázek, jako je pominutí závazků podle Úmluvy OSN o právech osob s postižením nebo nepř́mo podle judikatury Soudu skryté v odporu vůči školské inkluzi, může vyznívat jako nošení sov do Athén.

Jinými slovy, obrázek vypadá téměř idylicky, Česká republika takřka všechno plní, ale zdání může klamat a situace se může postupně nepř́iznivě vyvinout. Výslovná angažovanost všech státních mocí, nejenom té soudní, se tak v zájmu naplňování našich lidskoprávních závazků může změnit v nezbytnost.

1 Jak bylo uvedeno ve Zprávě za rok 2019 o stavu vyriquváni stížností podaných ke mezinárodním orgánùm ochrany lidských práv předložené vládě, ke konci roku 2019 , [z] Jhruba u poloviny z nevyrízených stǐ̌ností neodpovidá postup jejich projednáváni cílovému schématu dle bodu 20 písm. h) problášení z. Brightonu, podle něhož rozhodnutí o oznámeni stižnosti má padnout do roka od jejího podáni a o oznámených stižnostech má být roz̧hodnuto do dvou let od jejich oznámeni žalovanému státu. Skutečností je, že z 62 oznámených a nevyriżených stižnostíproti Ceské republice, jak je evidujeme ke dni 1. kvétna 2020, jüch bylo 48 podáno préd rokem 2018 (z. toho ty nejstarši ćtyři dokonce v roce 2012 a dalšich jedenáct v roce 2013)"(s. 22). V roce 2020 se tato situace významně nezměnila, jen u jedné z nejstarších stížností byl vydán rozsudek.

2 Rozsudek velkého senátu ze dne 13. listopadu 2007, D. H. a ostatní proti Céské republice, č. 57325/00. Postup výkonu lze sledovat v databázi HUDOC-Exec z: http:/ /hudoc.exec.coe.int/eng?i=004-31 


\subsection{Role vládního zmocněnce}

Vládní zmocněnec pro zastupování před Evropským soudem pro lidská práva (potažmo před dalšími mezinárodními orgány ochrany lidských práv) je ředitelem odboru na Ministerstvu spravedlnosti, a tedy státní úředník. Při vyřizování stížností komunikuje s prríslušným okruhem státních orgánů ,dotčených'v každém jednotlivém případě. Mezi ně patří zpravidla i soudy. Obvykle totiž v projednávané věci rozhodovaly předtím, než s ohledem na zásadu procesní subsidiarity vyjádřenou pravidlem vyčerpání vnitrostátních prostředků nápravy vůbec mohlo proběhnout řízení před mezinárodním soudem. Po rozsudku Soudu, a někdy již po oznámení stížnosti, kdy se některé nedostatky mohou jevit jako nad slunce jasné, je nezbytné o porušeních Úmluvy komunikovat s dotčenými orgány s cílem dosáhnout nápravy. Taková náprava může být nezbytná v individuální nebo v systémové rovině (jedná se po řadě o to, napravit situaci stěžovatele uvedením v předešlý stav potud, pokud to jde, a neopakovat tytéž chyby v jiných prrípadech).

Uvedené platí i pro vrcholné soudy. Ačkoli debata s nimi může být jednodušší (vybudovaly si zázemí v podobě analytických útvarů zaměřených na evropské či srovnávací právo, takže dokáží hovořit podobným jazykem jako lidé, kteří se zabývají mezinárodními závazky), musíme si být v naší komunikaci vědomi rizika protiprávního ovlivňování. Nezávislost a nestrannost soudů musíme respektovat; patř́ mezi záruky spravedlivého procesu a předpoklady právního státu. Zrrídkakdy si můžeme dovolit jednat neformálně, ač taková cesta bývá často nejúčinnější. Není také bez významu, že řízení o stížnostech v naprosté většině prrípadů odráží vertikální vztah mezi jednotlivcem coby nositelem základních práv a státem, jenž nositelem takových práv naopak není. Z toho vyplývá, že i cesty k řešení obvykle probíhají po této linii, kdy stát může navrhovat řešení ve svůj relativní neprospěch, a to s cílem zajistit uspokojivý výkon rozsudku Soudu a uzavření dohledu nad výkonem ze strany Výboru ministrů Rady Evropy.

Máme za sebou judikaturu Soudu, o které můžeme informovat, a tím naznačovat, jaké chování je s ní v souladu. Soudům však také musíme ponechávat volbu prostředků. Ne vždycky se naše konkrétní představa o implementaci setká s pochopením a dočká realizace. ${ }^{3} \mathrm{~V}$ tomto se soudy zásadně neliší od jiných státních orgánů, jen vůči nim nelze

3 Není namístě předbíhat, nicméně diskuse vedená o promítnutí závěrů Soudu ve věci Blokbin proti Rusku (rozsudek velkého senátu ze dne 23. března 2016, č. 47152/06) do naší právní úpravy soudnictví nad dětmi mladšími 15 let pro činy jinak trestné ukázala, že příslušný vrcholný soud s cílem bránit změně dokáže využít klasického argumentačního arzenálu založeného v prvé řadě na tom, že o nás přece Soud nerozhodoval (z čehož plyne nezávaznost ve světle čl. 46 odst. 1 Úmluvy) a naše právní úprava je jiná. Diskusi jsme otevřeli na pozadí kolektivní stížnosti podané k Evropskému výboru pro sociální práva (International Commission of Jurists proti Ceské republice, č. 148/2017), o jejíž odůvodněnosti vydal řečený výbor dne 20. října 2020 rozhodnutí a v něm zčásti shledal nesoulad s Evropskou sociální chartou. 
cokoli vehementně prosazovat. ${ }^{4}$ Diskuse obvykle probíhá v obecné rovině, bez zrèetele ke konkrétním případům, snad s výjimkou situací, kdy věc rozhodnutá ve Štrasburku vyžaduje přijetí individuálních opatření k nápravě. Vyjma takových porušení Úmluvy, jako je nepřiměřená délka soudního řízení, ve věci zpravidla rozhoduje plénum Ústavního soudu na základě návrhu na obnovu řízení o původně podané ústavní stížnosti. Vládní zmocněnec rozhodně nemá takový vliv, aby změnil názor pléna; nikdy však nebylo ničeho takového zapotřebí.

Pro dialog se soudy - vedený zpravidla skrze předsedu soudu, tedy orgán státní správy soudnictví - se jako obzvláště vhodné jeví ptát se na názor a klást otevřené otázky ohledně toho, zda podle jejich mínění rozsudek Soudu vyžaduje provedení nějakých změn nad rámec obeznámení soudců, kteří podobné věci rozhodují, s právním názorem Soudu, a pokud ano, tak jaké. ${ }^{5}$ Není ostatně primární odpovědností soudů zajistit implementaci rozhodnutí mezinárodního orgánu, ale mnohdy je implementace přes úpravu judikatury nejsnazší, zejména když vrcholné soudy mají ,na skladě takovou nerozhodnutou věc, v níž se přímo nabízí úpravu judikatury promítnout (v žargonu se tomu říká ,podvozek`).

Vcelku se nabízí, že o cestách k implementaci rozsudku Soudu je lepší komunikovat mezi zasvěcenými než činit čistě jednostranné kroky, jak se již v minulosti stalo, ${ }^{6}$ a to zvláště

4 Lze tu připomenout historickou debatu o výkonu rozsudků týkajících se vytěsňování menšinových akcionářů, která se do našeho právního řádu i judikatury vrcholných soudů promítla nakonec velice omezeně, a to skrze změnu zákona č. 125/2008 Sb., o přeměnách obchodních společností, provedenou zákonem č. 355/2011 Sb. K tomu též nálezy Ústavního soudu ze dne 3. března 2011, sp. zn. III. ÚS 2671/09, a ze dne 21. března 2011, sp. zn. I. ÚS 1768/09, a usnesení Nejvyššího soudu ze dne 30. března 2011, sp. zn. 29 Cdo 1048/2008. Třebaže naše původní úvahy směřovaly k tomu, že by určení protiprávnosti rozhodnutí většinového akcionáře mělo mít za důsledek jejich neplatnost, konzultace nejrůznějších orgánů, včetně obou uvedených vrcholných soudů, vedla k závěru, že budou z protiprávnosti vyvozeny jiné důsledky. Nelze tu ovšem hovořit o žádné vyhrocené debatě s našimi soudy. Šlo o rozsudky ve věcech Koblhofer a Minarik proti Ceské republice (ze dne 15. října 2009, č. 32921/03 a dalšî) a Minarik proti Ceské republice (ze dne 10. února 2011, č. 46677/06), jakož i některé další, když problematika ochrany menšinových akcionářů vyvolala vlnku stížností $\mathrm{k}$ Soudu. Informace o výkonu těchto rozsudků jsou dostupné z: http:/ / hudoc.exec.coe.int/eng?i=001-141144

5 Na přelomu let 2020 a 2021 provádíme takovou konzultaci po rozsudku ze dne 25. června 2020, Tempel proti Ceské republice, č. 44151/12, a zjišst'ujeme věcné poznatky i postřehy všech vyšších soudů, které rozhodují v trestních věcech, na uplatňování \ 262 trestního řádu, který odvolacímu soudu umožňuje, aby po zrušení prvostupňového rozhodnutí při vrácení věci nařídil, aby byla projednána v senátu s odlišným složením, př́padně věc odňal dosavadnímu soudu prvního stupně a prrikázal ji k projednání jinému.

6 Ústavní soud sdělení svého pléna, vydané pod č. 32/2003 Sb., nekonzultoval. Mělo odpovědět na první rozsudky Soudu ohledně vztahu dovolání a ústavní stížnosti (rozsudky ze dne 12. listopadu 2002, Zvolský a Zvolské proti Ceské republice, č. 46129/99, a Běleš a ostatníproti Ceské republice, č. 47273/99) a bohužel žádné řešení problému nepřineslo. Stejně tak Ústavní soud nepovažoval za nutné zjistit náš názor, když se rozhodl sáhnout k obnově rízení nikoli po odsuzujícím rozsudku Soudu, ale po akceptování jednostranného prohlášení vlády (rozhodnutí ze dne 26. listopadu 2013, Jahoda proti Ceské republice, č. 28768/09); usnesení pléna Ústavního soudu ze dne 9. prosince 2014, sp. zn. Pl. ÚS 6/14). Naproti tomu Ústavní soud vyžádal naše vyjádření ve věci sp. zn. II. ÚS 604/02, která souvisela se smírným urovnáním stížnosti Cerveñáková a ostatni proti Ceské republice (rozsudek ze dne 29. července 2003, č. 40226/98), a řízení o ústavní stížnosti usnesením ze dne 26. února 2004 zastavil právě s ohledem na podmínky smírného urovnání. 
v situaci, kdy vládní zmocněnec odpovídá za koordinaci implementačního úsilí a referuje o jeho výsledcích Výboru ministrů Rady Evropy v rámci jeho dohledu nad výkonem rozsudků Soudu. Navzdory některým negativním zkušenostem však lze říci, že komunikace funguje docela uspokojivě.

Mohou se objevit domněnky, zda vládní zmocněnec jako součást Ministerstva spravedlnosti vede v rámci koordinace výkonu rozsudků Soudu s vnitrostátními soudy přetahovanou mezi státními mocemi, prì této aktivitě zastupuje zájmy exekutivy a prosazuje je proti zájmu soudů. Tuto vizi reality považuji za neprriléhavou. Snažíme se zásadně vést se všemi dotčenými orgány dialog s cílem nalézt adekvátní řešení implementačního problému, snad z toho důvodu, že jsme se naučili reprezentovat stát jako celek, nikoli jeho jednotlivé orgány, jejichž pohledy na věc vskutku mohou být protikladné. Ačkoli nelze vyloučit, že Soud vysloví právní názor, s nímž budou naše soudy nebo jiné orgány ostře nesouhlasit, jedním z účinků konzultace dotčených orgánů již ve fázi obhajoby je, že silné a opodstatněné názory mohou - a také by měly - být vtěleny do stanoviska vlády. Úkolem Soudu pak je, aby na ně náležitě reagoval, jinak vytvoří napětí, které může výrazně zkomplikovat následný výkon rozsudku.

\section{Zkoumaná mikroúroveň}

Jak už bylo uvedeno, výzkum samotný se zaměřil na tři úrovně - makro-, mezo- a mikroúroveň. Takový př́stup poskytuje poměrně komplexní pohled na celou problematiku. $\mathrm{V}$ rámci mikroúrovně nebylo logicky možné věnovat pozornost všemu, co by si ji zasloužilo, a tak nezbylo než se uchýlit $\mathrm{k}$ vysoké míre selektivnosti. Než se budu věnovat mikroúrovni, chtěl bych ocenit, že se výzkum opřel o vlastní algoritmy pro zkoumání makroúrovně, tedy celkového obrazu o tom, do jaké míry se vyskytují odkazy na judikaturu Soudu v rozhodnutích našich vrcholných soudů. Při zkoumání rozsáhlých souborů dat a databáze vrcholných soudů takové soubory obsahují - nutně narážíme na obtiže, které začínají u nejednotného způsobu citování judikátů Soudu, procházejí přes mezerovitou identifikaci použitých norem (kdyby bylo vždy v metadatech uvedeno použití Úmluvy, výrazně by to analýzu zjednodušilo) až po obtížné automatizované určování, jaký smysl měl ve vnitrostátním judikátu odkaz na nějaké rozhodnutí Soudu; to bylo zkoumáno na mezoúrovni.

$\mathrm{V}$ rámci mikroúrovně se výzkum snažil pojmenovat př́klady toho, jak se ten který vrcholný soud vypořádal s požadavky vyplývajícími z judikatury Soudu. Neznamená to nutně, že české soudy uplatnily Úmluvu zcela správně, že z ní např́iklad nepřevzaly jen některé aspekty, zatímco pominuly jiné, a tak by se rozhodnutí Soudu, pokud by bylo vydáno, nemuselo shodovat s rozhodnutím, $\mathrm{k}$ němuž dospěl náš soud. 


\subsection{Nejvyšší soud}

U Nejvyššího soudu se výzkum zabýval zaprvé odškodněním nemajetkové újmy za protiprávní zbavení svobody ve smyslu čl. 5 odst. 5 Úmluvy. Vývoj, který tu nastal před vydáním zákona č. 160/2006 Sb., jímž byl novelizován zákon o odpovědnosti státu za škodu způsobenou nezákonným rozhodnutím nebo nesprávným úředním postupem, byl jistě žádoucí, nebot' nebylo zřejmé, zda náš právní systém skutečně ve všech prrípadech protiprávního zbavení svobody umožňuje poskytnout peněžitou náhradu způsobené újmy. Uvedená novela přistoupila ostatně k provedení čl. 5 odst. 5 Úmluvy minimalisticky, když vložila nový \6a, který jen odkazuje na existenci odpovědnosti státu a územních celků v samostatné působnosti za porušení práva na osobní svobodu. Bylo by dosti obtížné podrobněji popsat všechny případy, kdy by přicházelo v úvahu použití článku 5 Úmluvy. Zadruhé, vůle po odškodnění politických vězňů zjevně odráží nutnost překlenout nedokonalost právní úpravy. Tato situace ostatně vyvstala v oblasti rehabilitací a restitucí vícekrát a bylo obtížné ji řešit řádnou legislativní cestou. To také vysvětluje, proč se Nejvyšší soud i Ústavní soud nakonec nechaly přesvědčit k tomu, že musí rozsudky Soudu o nepřiměřeném břemeni uvaleném právní úpravou na povinné osoby v restituci implementovat judikatorní cestou. ${ }^{7}$ Jinak je ale obtížné souhlasit s tím, že by nárok na náhradu za zbavení svobody v době před vstupem Úmluvy pro Českou republiku v platnost vyplýval z Úmluvy.

Zatřetí, Nejvyšší soud reagoval na poslední vývoj judikatury Soudu v oblasti souběhu daňového a trestního postihu. Soud naposledy na úrovni velkého senátu ${ }^{8}$ rozvinul sérii kritérií, při jejichž splnění lze tolerovat dvě sankční řízení o tomtéž skutku (daňové penále či jiný podobný institut na straně jedné a trestní postih na straně druhé). Nejvyšší soud se pokusil náš systém obhájit a na základě štrasburských požadavků dovodit, že obstojí. Potíž je v tom, že pokud by mělo být daňové řízení opravdu více propojeno s trestním stíháním, vyžádalo by si to nepochybně systémový zásah, kdy by nebylo úplně možné, aby orgány činné $\mathrm{v}$ trestním řízení šetřily zcela samostatně to, nač daňové orgány poukazují.

\subsection{Nejvyšší správní soud}

Má předně s Nejvyšším soudem společné téma ne bis in idem, ne však v rovině souběhu správního trestání a trestního řízení, ale v rovině postupného postihování téhož jednání v různých správních řízeních. Lze se domnívat, že svou snahou popřít jinak pravděpodobné důsledky judikatury Soudu v dané oblasti, kdy v podstatě totéž jednání zakládá prvek idem bez ohledu na možnost jeho různé právní kvalifikace, se pokusil předejít nutnosti systémových změn, kdy by bylo nezbytné mnohem více koordinovat správní

\footnotetext{
7 Této problematice je $\mathrm{v}$ dalším textu ještě jednou věnována pozornost.

8 Rozsudek velkého senátu ze dne 15. listopadu 2016, A a B proti Norsku, č. 24130/11 a 29758/11.

9 Usnesení velkého senátu trestního kolegia ze dne 4. ledna 2017, č. j. 15 Tdo 832/2016-126.
} 
postih ze strany různých orgánů. Ani v prrípadě souběhu daňového a trestního řízení, ani v prŕpadě souběhu dvou správních sankčních řízení v České republice se však dosud neměl Soud př́ležitost vyjádřit. České vládě zatím ani nebyla oznámena žádná příhodná stížnost na tuto problematiku.

Dále výzkumníci zvolili poukaz na přenesení záruk spravedlivého procesu do prostředí našeho správního řízení a soudního řízení správního. Článek 6 Úmluvy v něm obsažené záruky směřuje na soudní řízení, přičemž ve správním soudnictví před jeho reformou v roce 2002 vi̊bec vyvstávala otázka šiře soudního přezkumu, který ve většině případů neprobíhal za podmínky úplné přezkumné pravomoci správních soudů (většinou byla omezena na otázky právní a soudy toliko vycházely ze skutkových okolností zjištěných správními orgány). Naše úprava správního řízení obsahuje řadu pravidel, která proces připodobňují tomu, jak by měly postupovat soudy samotné, když mají dodržet zásady práva na spravedlivý proces. Na řízení o nějakém občanském právu či svobodě anebo o odůvodněnosti trestního obvinění, jak o tom hovoří čl. 6 odst. 1 Úmluvy, je třeba nahlížet jako na celek, a tak pokud předchozí správní řízení dokáže zajistit splnění určitých zásad, může být následný soudní přezkum o to efektivnější. Jde ostatně o to, aby se účastníkovi dostalo nejlépe nejenom objektivně, ale také subjektivně spravedlivého zacházení v jakékoli fázi. Postupy správních soudů před reformou i po reformě se v několika př́padech staly předmětem přezkumu u Soudu; odhalené problémy byly vyřešeny, at' už plným provedením reformy, nebo dílčí novelizací. ${ }^{10}$

Následný poukaz na posouzení zákonnosti politických stran, konkrétně Dělnické strany, by bývalo bylo vhodné doplnit o informaci, že Soud postup našich soudů skutečně aproboval, což u jiných př́kladů analyzovaných v rámci mikroúrovně chybí. Bohužel nejinak tomu je i zde: stěžovatelská strana a její předseda na stanovisko vlády neodpověděli, Soud řízení o jejich stížnosti zastavil, a tak jsme se posouzení jejich námitek nedočkali. ${ }^{11}$ Konečně př́klad, v němž se Nejvyšší správní soud jednoznačně odchýlil od právního názoru Soudu, spočívá v požadavku předchozí sterilizace (znemožnění reprodukční schopnosti jednotlivce) pro účely úřední změny pohlaví. Existuje tu nejenom jasná judikatura Soudu, kterou, ač je senátní, Soud sám označil nejvyšším stupněm důležitosti, ${ }^{12}$

10 Největší výzvu ve správním soudnictví představovalo zajištění dostatečné šíře soudního přezkumu sporného občanského práva nebo závazku, případně oprávněnosti trestního obvinění. Př́ikladmo lze poukázat na rozsudky: rozsudek ze dne 21. řijna 2003, Kreditni a primyslová banka proti Ceské republice, č. 29010/95; rozsudek ze dne 7. prosince 2004, Kilián proti Ceské republice, č. 48309/99; rozsudek k odůvodněnosti ze dne 31. července 2008, Drušstevní źáložna PRIA a ostatní proti České republice, č. 72034/01; nebo rozsudek ze dne 2. října 2014, Delta pekárny a. s. proti Ceské republice, č. 97/11 (kde šlo porušení článku 8, ale také z důvodu šíre přezkumu). V rozsudku velkého senátu ze dne 19. září 2017, Regner proti Ceské republice, č. 35289/11, jenž se týkal jiného aspektu práva na spravedlivý proces před správním soudem (přístupu žalobce k utajovaným informacím v řízení o přezkumu neudělení či odnětí bezpečnostní prověrky), byla obhajoba státu před Soudem úspěšná.

11 Rozhodnutí výboru ze dne 26. března 2013, Dělnická strana a Vandas proti Ceské republice, č. 70254/10.

12 Rozsudek ze dne 6. dubna 2017, A. P., Garçon a Nicot proti Francii, č. 52471/13 a 52596/13. 
ale také kvazijudikatura Evropského výboru pro sociální práva, ${ }^{13}$ která směřuje proti České republice a vhodně shrnuje jednotný náhled mezinárodních orgánů. Bohužel se toto rozhodnutí navzdory včasné snaze dosud nepodařilo implementovat. Chybí zde jasná vưle vlády implementaci zajistit. Ani projednání odpovídajícího podnětu Radou vlády pro lidská práva ${ }^{14}$ nepřineslo žádný výsledek. Záležitost tak zůstává obětí nynějšího způsobu fungování Poslanecké sněmovny bez jasného řízení, jehož chaotičnost a neefektivnost se, jak se zdá, v tomto volebním období prohloubily. Každopádně rozsudek Nejvyššího správního soudu, který se v podstatě ,chytil‘ odlišného stanoviska v citované věci rozhodnuté Soudem, a nikoli názoru většiny, jemuž Soud přiznal váhu autority, je stále předmětem posouzení ze strany Ústavního soudu. ${ }^{15}$

\section{3 Ústavní soud}

Pokud jde o svobodu projevu, známkou úspěchu Ústavního soudu i našich obecných soudů, které se zabývají ochranou osobnosti, může být, že stížnosti na tuto problematiku, které by byly oznámeny české vládě, jsou nesmírně zrrídkavé. ${ }^{16}$ Žádné opravdu mediálně známé věci, u nichž by se očekávalo, že skončí ve Štrasburku. Může tomu tak být, ale zůstávají tam bez odezvy. Naproti tomu změna v náhledu Ústavního soudu na otázku pozitivní povinnosti vést účinné vyšetřování nebyla úplně spontánní, jelikož ji vyvolal tlak vyplývající z oznámených a rozsudkem rozhodnutých stížností podaných k Soudu. ${ }^{17}$

Výzkumníci mohli zajisté zvolit řadu dalších příkladů, jak by ostatně odpovídalo tomu, že nejvyšším strážcem základních práv a svobod v naší zemi je právě Ústavní soud.

Mohli bychom pomyslet např́klad na již zmíněnou otázku výše náhrady přiznávané povinným osobám v restituci, kde Ústavní soud spolu s Nejvyšším soudem poté, co se dočkaly vhodného ,podvozku', ve světle judikatury Soudu akceptovaly, že náhradu nelze omezit toliko na minimum, které restituční zákony výslovně zakotvovaly. Toto

13 Kolektivní stížnost č. 117/2015, rozhodnutí o odůvodněnosti ze dne 15. května 2018, Transgender Europe a ILGA-Europe proti Ceské republice.

14 Usnesení Rady vlády pro lidská práva ze dne 11. března 2019 k otázce práv trans osob. Je pravda, že rada tu pouze „doporučuje [...] ministru spravedlnosti ve spolupráci s [...] ministrem vnitra a ministrem zdravotnictví

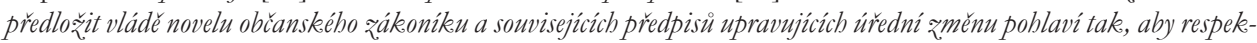
tovala roz̧hodnuti Evropskébo soudu pro lidská práva a Evropskébo výboru pro sociální práva“. Odkaz na mezinárodní závazky je tu však jasný, navíc Ministerstvo spravedlnosti bezprostředně po vydání rozhodnutí Evropského výboru pro sociální práva př́hodnou novelu připravilo. Usnesení rady zůstalo zcela bez odezvy.

15 Věc sp. zn. Pl. ÚS 2/20.

16 Byly vlastně jen dvě: rozsudek ze dne 18. července 2006, Štefanec proti Ceské republice, č. 75615/01 (porušenî) a rozsudek ze dne 2. února 2012, Růžový panter, o. s., proti Ceské republice, č. 20240/08 (neporušenî).

17 Rozsudek ze dne 16. února 2012, Eremiášová a Pechová proti Céské republice, č. 23944/04; rozsudek ze dne 18. řijna 2012, Bureš proti Ceské republice, č. 37679/08; nebo rozsudek ze dne 25. července 2013, Kummer proti Ceské republice, č. 32133/11. 
minimum spočívalo v podstatě ve vrácení původně, často před desítkami let zaplacené kupní ceny, jež naprosto neodpovídala hodnotě nemovitých věcí v době, kdy bylo rozhodnuto o povinnosti je vydat v restituci oprávněným osobám. ${ }^{18}$ Je pravda, že v návaznosti na první takové rozsudky z listopadu $2002^{19}$ byla posuzována možnost požádat o postoupení věci velkému senátu, ale nakonec se k tomu kroku neprristoupilo. Tato judikatura se u Soudu stejně prosadila a upřesnila, co se týče použitelných kritérií. ${ }^{20}$

Podobně v oblasti náhrady za protiprávní regulaci nájemného selhal zákonodárce, když nepřijal patřičnou právní úpravu, která by problém systémově řešila. Zde ovšem Ústavní soud a Nejvyšší soud reagovaly opravdu záhy po vydání potřebných rozsudků ve Štrasburku ${ }^{21}$ a uzpo̊sobily kritéria stanovení náhrady právnímu názoru Soudu. ${ }^{22}$ Je obtížné hovořit o tom, že se tak stalo rychle, ale stalo se tak skutečně nedlouho poté, co Soud konečně, po mnoha letech, tuto materii rozhodl, třebaže tomu předcházel jeden záchvěv odporu, ${ }^{23}$ který se posléze zhmotnil ve stížnost k Soudu. ${ }^{24}$

Oba tyto př́klady ukazují, že bylo pro zákonodárce obtížné náležitě reagovat, a to nejspíše z obav z otevření pomyslné Pandořiny skříňky, kdy z dobře míněného návrhu zákona může vzejít něco, co původnímu záměru předkladatele vůbec neodpovídá. $\mathrm{V}$ těchto konkrétních př́padech blokace vyvolaná obavami nastala na úrovni ministerstev a ani dlouhé debaty vedené ve své době mezi ministerstvy pro místní rozvoj, financí a spravedlnosti $\mathrm{v}$ rámci vyřizování stížností na regulaci nájemného nevyústily v žádný návrh na odčinění způsobených křivd, pouze v samu o sobě nesmírně žádoucí změnu právní úpravy nájemních vztahů jako takovou.

18 Nález pléna Ústavního soudu ze dne 23. dubna 2013, sp. zn. Pl. ÚS 33/10; rozsudky Nejvyššího soudu ze dne 17. února 2010, sp. zn. 28 Cdo 2202/2009, ze dne 31. srpna 2010, sp. zn. 28 Cdo 4935/2009, ze dne 13. února 2013, sp. zn. 28 Cdo 2882/2012 (tatáž věc jako sp. zn. 28 Cdo 2202/2009, svědčící o tom, že se Ministerstvo financí jako žalovaná strana vytrvale bránilo takovému výkladu \11 zákona č. 87/1991 Sb., o mimosoudních rehabilitacích, který je v souladu s judikaturou Soudu).

19 Rozsudek ze dne 5. listopadu 2002, Pincová a Pinc proti Ceské republice, č. 36548/97; a Zvolský a Zvolská proti Čské republice (cit. výše). Oba rozsudky Soud označil stupněm významnosti 1 , čímž je zařadil mezi své nejvýznamnější judikáty.

20 Rozsudek ze dne 15. března 2007, Velikovi a ostatni proti Bulharsku, č. 43278/98 a další.

21 Rozsudek ke spravedlivému zadostiučinění ze dne 9. února 2017, Cápský a Jeschkeová proti Ceské republice, č. 25784/09 a 36002/09, a rozsudek z téhož dne, Heldenburgovi proti Ceské republice, č. 65546/09.

22 Rozsudek velkého senátu občanskoprávního a obchodního kolegia Nejvyššího soudu ze dne 13. prosince 2017, sp. zn. 31 Cdo 1042/2017, a nález Ústavního soudu ze dne 4. ledna 2018, sp. zn. IV. ÚS 2326/16, překonaly předchozí judikaturu obou soudů.

23 Usnesení Ústavního soudu ze dne 21. března 2017, sp. zn. I. ÚS 298/17, tedy z doby, kdy relevantní rozsudky Soudu dosud nenabyly právní moci. Je zajímavé, že soudkyni zpravodajku v této věci téměř nelze podezírat z toho, že by nebyla Štrasburku nakloněna. Ve skutečnosti by pro věc samu bývalo bylo moudřejší počkat, nikoli za každou cenu, čistit stůl‘.

24 Volná proti Ceské republice, č. 33675/17, která skončila smírným urovnáním schváleným rozhodnutím ze dne 12. září 2019, Stuchlý a ostatni proti Ceské republice, č. 63451/16. 


\subsection{Romské děti zařazené mimo hlavní vzdělávací proud}

Výzkumníci věnovali této záležitosti zvláštní pozornost, a jak už bylo zmíněno, rozsudek Soudu ve věci $D$. H. a ostatní nebyl dosud uspokojivě vykonán, navzdory mnoha změnám, jimiž školský systém prošel, i značnému objemu finančních prostředků, jež byly věnovány inkluzivnímu vzdělávání. Ústavní soud, když se zabýval ústavní stížností, která předcházela předložení věci Soudu, z posuzovaného problému diskriminace vybruslil s konstatováním, že by ho měly př́islušné orgány řešit, ${ }^{25}$ a proto se do dějin boje s diskriminací romské menšiny svým odmítacím usnesením významně nezapsal.

Celkově vzato však tato problematika, at’ už jde o diskriminaci ve školství nebo diskriminační žaloby vůbec, nepatř́ mezi ty, jimiž se naše soudy typicky zabývají. U pozoruhodné kauzy J. S., jež prošla všemi stupni soudní soustavy a je objektivně sporná minimálně z časového hlediska (dotyčný poukazuje na svoje dávné zařazení do zvláštní školy), nemáme zprávy o tom, zda se jí Soud hodlá zabývat, ba ani o tom, zda byla stížnost do Štrasburku opravdu podána. ${ }^{26}$

Příslušníci romské menšiny, z důvodů, které se vcelku nabízejí, zřídkakdy vedou soudní spory, a tak je zpravidla potřeba nějaké vnější pomoci, obětavosti či zvláštního nasazení právního zástupce nebo nevládní organizace k tomu, aby tyto spory vưbec proběhly. Nejinak tomu bylo i ve věci $D$. H. a ostatní. Přitom je spíše pravděpodobné, že tlak soudů - které by nejspíše dospěly po nějaké době k závěru, jenž by byl v souladu s mezinárodními závazky -, spojený s finančními postihy vưči školám, potažmo jejich zřizovatelům, v podobě peněžitého zadostiučinění, které lze na základě antidiskriminačních žalob přiznat, by mohl minimálně přispět k nastolení žádoucích vzorců chování. Jak už bylo také řečeno, z Úmluvy o právech osob s postižením, jež je přímo závazná, vyplývá právo na inkluzivní vzdělávání.

\section{Závěr}

V úvodu zaznělo, že tento výzkum zapadá do probíhající vlny zájmu o prozkoumání problematiky dodržování lidskoprávních závazků státy. Je to pro nás významný kamínek v mozaice, která ještě zdaleka nebyla dotvořena. Bylo by nepochybně podnětné zprostředkovat českému prostředí výsledky tohoto výzkumného úsilí jako celku.

25 Usnesení ze dne 20. ř́ijna 1999, sp. zn. I. ÚS 297/99.

26 Rozsudek Nejvyššího soudu ze dne 13. prosince 2012, sp. zn. 30 Cdo 4277/2010; usnesení Ústavního soudu ze dne 12. srpna 2015, sp. zn. III. ÚS 1136/13. 